\title{
Effect of Epoxy Coating Thickness on Bond Strength of Reinforcing Bars
}

\author{
by Gerald G. Miller, Jennifer L. Kepler, and David Darwin
}

\begin{abstract}
The effect of epoxy coating thickness on bond strength is evaluated using No. 19 (No. 6) reinforcing bars with coating thicknesses ranging from 160 to $510 \mu \mathrm{m}$ (6.4 to 19.9 mils). Three deformation patterns are evaluated using epoxy meeting the requirements of ASTM A 775. The reduction in bond strength caused by epoxy coatings between 160 and $420 \mu \mathrm{m}$ (6.4 and 16.5 mils) is largely independent of coating thickness. The reduction, however, becomes significant for coatings thicker than $420 \mu \mathrm{m}$ (16.5 mils). When combined with earlier research on bars ranging in size from No. 10 to No. 36 (No. 3 to No. 11), the results demonstrate that an increase in the maximum allowable coating thickness, from $300 \mu \mathrm{m}$ to $420 \mu \mathrm{m}$ (12 to 16.5 mils), is justified for No. 19 (No. 6) and larger reinforcing bars in the ASTM standard.
\end{abstract}

Keywords: bond; coating; deformed reinforcement; epoxy; reinforcement; rib.

\section{INTRODUCTION}

Epoxy-coated steel reinforcing bars are widely used in concrete construction to improve corrosion resistance. The coating, however, causes a reduction in bond strength between reinforcing bars and concrete. As a result, the ACI Building Code (ACI 318-02) and the AASHTO Bridge Specifications (1996) require the use of a development length modification factor of 1.5 for most applications. Current standards (ASTM A 775 and A 934) allow coating thicknesses between 175 and $300 \mu \mathrm{m}$ ( 7 and 12 mils) to be used. Thicker coatings would provide greater toughness and enhance the ability of the epoxy to protect the steel but are not permitted because of concern about the effect on bond.

Choi et al. $(1990,1991)$ evaluated the effect of coating thickness on the bond strength of epoxy-coated bars. Their work shows that for epoxies meeting the requirements of ASTM A 775, coating thickness has no significant effect on bond strength as it increases from 76 to $300 \mu \mathrm{m}$ ( 3 to 12 mils) for No. 19 (No. 6) bars and from 76 to $356 \mu \mathrm{m}$ ( 3 to 14 mils) for No. 25 (No. 8) bars. For No. 16 (No. 5) bars, however, the study shows a decrease in bond strength as coating thickness increases, even for values below $300 \mu \mathrm{m}$ (12 mils). It would be desirable in many cases to increase the maximum allowable coating thickness.

The tests by Choi et al. (1990, 1991), combined with those by Hester et al. (1991), on bars ranging in size from No. 10 (No. 3) to No. 36 (No. 11), indicate that the bond strength of smaller bars is more adversely affected than the bond strength of larger bars by thicker coatings and an increase in the allowable maximum coating thickness from $300 \mu \mathrm{m}$ (12 mils) to $356 \mu \mathrm{m}$ (14 mils) is justified for No. 25 (No. 8) and larger bars. The $356 \mu \mathrm{m}$ (14 mils) limit results from the fact that, except for one specimen, $356 \mu \mathrm{m}$ (14 mils) was the thickest coating used in the tests. The early studies also demonstrate that bars as small as No. 19 (No. 6) are not adversely affected by increases in coating thickness, but that evidence is limited to bars with a maximum coating thickness of $300 \mu \mathrm{m}$ (12 mils).

The goal of the current study is to determine if thicker coatings may be used on No. 19 (No. 6) and, by extension, larger bars. To this end, No. 19 (No. 6) bars with average coating thicknesses ranging from 160 to $510 \mu \mathrm{m}$ (6.4 to 19.9 mils) are tested. Full details of the study are presented by Miller, Kepler, and Darwin (1998).

\section{RESEARCH SIGNIFICANCE}

Early research on epoxy-coated reinforcement (Mathey and Clifton 1976) demonstrated that $635 \mu \mathrm{m}$ ( 25 mil) epoxy coatings caused unacceptable reductions in bond strength, while coatings below $280 \mu \mathrm{m}$ (11 mils) caused much lower reductions. With the exception of work by Choi et al. (1990, 1991) and three tests by Hasan, Cleary, and Ramirez (1996), subsequent research on the effect of epoxy coatings has involved bars with a maximum coating thickness of $300 \mu \mathrm{m}$ (12 mils). The work reported in this paper is significant because it demonstrates that the maximum allowable thickness for epoxies meeting the requirements of ASTM A 775 can be safely increased to $420 \mu \mathrm{m}$ (16.5 mils) for No. 19 (No. 6) and larger reinforcing bars. Greater thicknesses will enhance coating toughness and improve corrosion resistance. A separate evaluation is recommended for the harder epoxy coatings that meet the requirements of ASTM A 934.

\section{EXPERIMENTAL PROGRAM}

The experimental program consisted of 72 beam-end specimens, fabricated and tested in accordance with ASTM A 944 , the standard used to qualify epoxy coatings based on bond strength. No. 19 (No. 6) test bars were obtained from three companies (deformation patterns are designated $\mathrm{B}, \mathrm{C}$, and $\mathrm{S}$ ). For each deformation pattern, tests were run on 12 uncoated bars and 12 coated bars, three each with nominal coating thicknesses of $175,300,380$, and $460 \mu \mathrm{m}(7,12,15$, and 18 mils). Actual coating thicknesses ranged from 160 to $510 \mu \mathrm{m}$ (6.4 to 19.9 mils).

\section{Test specimens}

The test specimens (Fig. 1) were fabricated according to ASTM A 944 with a nominal cover of $38 \mathrm{~mm}$ (1.5 in.). Test bars were oriented with the longitudinal ribs in the vertical plane. Auxiliary reinforcement consisted of two uncoated No. 16 (No. 5) bars parallel to the test bar for flexural reinforcement

ACI Structural Journal, V. 100, No. 3, May-June 2003.

MS No. 02-059 received February 28, 2002, and reviewed under Institute publication policies. Copyright (C) 2003, American Concrete Institute. All rights reserved, including the making of copies unless permission is obtained from the copyright proprietors. Pertinent discussion including authors' closure, if any, will be published in the MarchApril 2004 ACI Structural Journal if received by November 1, 2003. 
Gerald G. Miller is a structural engineer with KPFF Consulting Engineers in Portland, Oreg. He received his $A B$ degree in math and German from Bowdoin College, and his $B S$ and MS in civil engineering from the University of Kansas, Lawrence, Kans.

Jennifer L. Kepler is a structural engineer with Peoples Associates Structural Engineers in Pleasanton, Calif. She received her BS and MS in civil engineering from the University of Kansas.

David Darwin, FACI, is the Deane E. Ackers Distinguished Professor of Civil Engineering and Director of the Structural Engineering and Materials Laboratory at the University of Kansas. He is Chair of ACI's TAC Technology Transfer Committee and ACI Committee 408, Bond and Development of Reinforcement, and is a member of the Financial Advisory Committee; ACI Committee 446, Fracture Mechanics; and Joint ACI-ASCE Committees 445, Shear and Torsion; and 447, Finite Element Analysis of Reinforced Concrete Structures. He is past Chair of the ACI Publications Committee and the Concrete Research Council, and a member and past Chair of ACI Committee 224, Cracking. He is also a past member of ACI's Board of Direction and the Technical Activities Committee.

and four No. 10 (No. 3) closed stirrups. No. 16 (No. 5) transverse bars were used in accordance with ASTM A 944. Prior to testing, cover was measured by placing a straight edge on top of the test specimen and measuring the distance from the straight edge to the top of the test bar to the nearest
1/16 in. (1.6 mm) using a ruler. Nominal embedment length, lead length, and cover were constant for all specimens at $267 \mathrm{~mm}$ (10.5 in.), $12.7 \mathrm{~mm}$ (0.5 in.), and $38.1 \mathrm{~mm}$ (1.5 in.), respectively (Fig. 1).

\section{Materials}

Reinforcing steel-The test bars were ASTM A 615 Grade 420 (60) No. 19 (No. 6) bars with three different deformation patterns (Fig. 2). The B bars had diagonal ribs ${ }^{*}$ oriented 70 degrees to the longitudinal axis, the $\mathrm{C}$ bars had diagonal ribs oriented 60 degrees to the longitudinal axis, and the $\mathrm{S}$ bars had ribs that were perpendicular to the longitudinal axis. The test bars for each deformation pattern came from the same heat of steel. Bar properties are listed in Table 1.

The epoxy coating was applied at nominal thicknesses of $175,300,380$, and $460 \mu \mathrm{m}(7,12,15$, and 18 mils $)$. With the exception of coating thickness, the epoxy was applied in accordance with ASTM A 775. Average coating thicknesses

\footnotetext{
${ }^{*}$ The terms deformations and ribs are used interchangeably in this study.
}

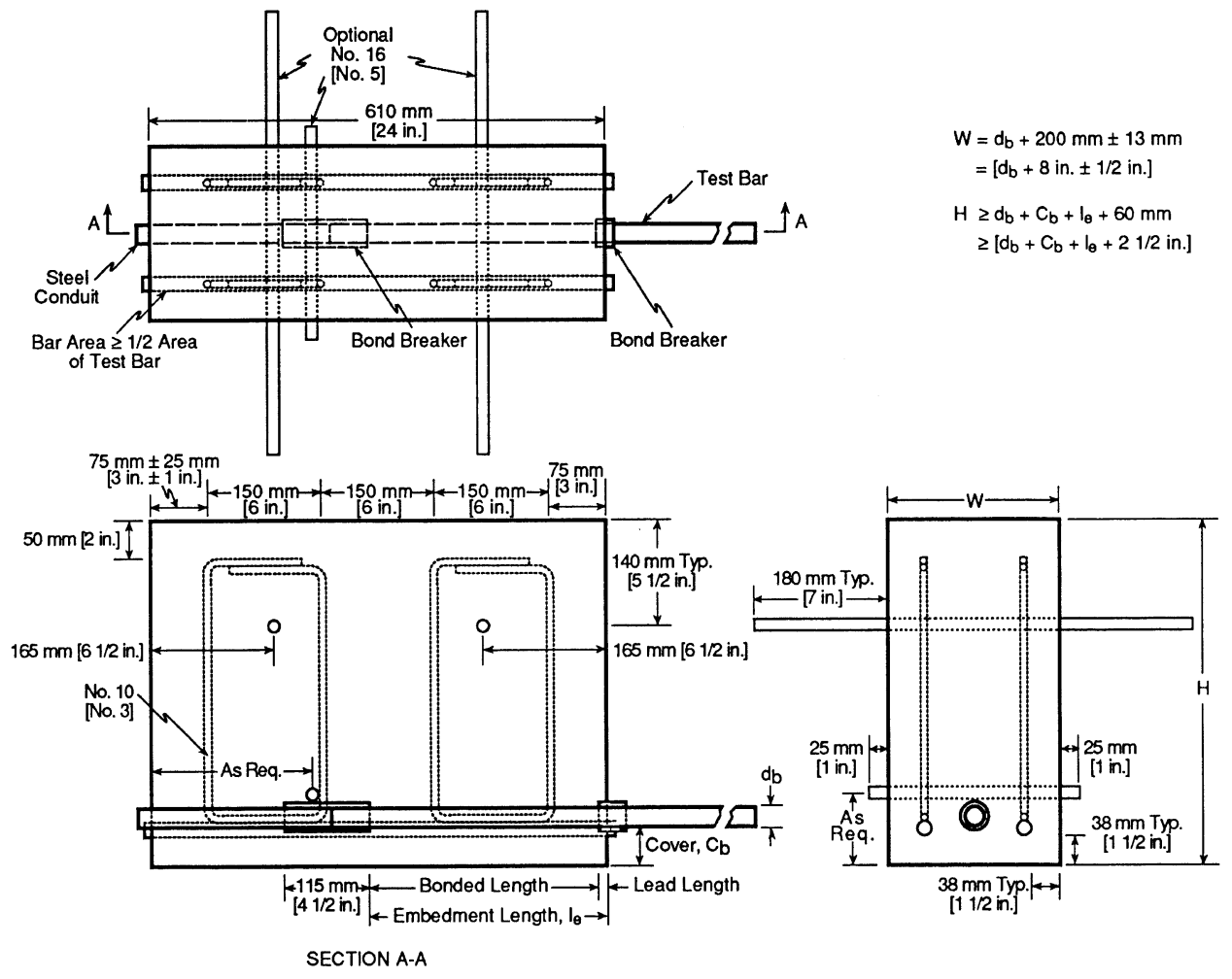

Fig. 1-Beam-end test specimen (ASTM A 944).

Table 1-Average test bar data

\begin{tabular}{|c|c|c|c|c|c|c|c|c|c|}
\hline \multirow{2}{*}{$\begin{array}{l}\text { Nominal bar } \\
\text { diameter, mm }\end{array}$} & \multirow{2}{*}{$\begin{array}{c}\text { Deformation } \\
\text { pattern }^{*}\end{array}$} & \multirow{2}{*}{$\begin{array}{c}\text { Yield } \\
\text { strength, MPa }\end{array}$} & \multicolumn{2}{|c|}{ Rib height } & \multirow[b]{2}{*}{ Rib spacing, mm } & \multirow[b]{2}{*}{ Rib gap ${ }^{\ddagger}$ mm } & \multirow{2}{*}{$\begin{array}{c}\text { Deformation } \\
\text { angle, degrees }\end{array}$} & \multirow{2}{*}{$\begin{array}{c}\text { Rib face } \\
\text { angle },{ }^{\S} \text { degrees }\end{array}$} & \multirow{2}{*}{$\begin{array}{l}\text { Relative } \\
\text { rib areall }\end{array}$} \\
\hline & & & Average, ${ }^{\dagger} \mathrm{mm}$ & ASTM, mm & & & & & \\
\hline 19 & $\mathrm{~B}$ & 437 & 1.07 & 1.15 & 10.4 & 2.92 & 70 & 42 & 0.093 \\
\hline 19 & $\mathrm{C}$ & 479 & 0.93 & 1.11 & 10.3 & 4.93 & 60 & 44 & 0.070 \\
\hline 19 & $\mathrm{~S}$ & 431 & 1.00 & 1.10 & 10.9 & 3.43 & 90 & 22 & 0.081 \\
\hline
\end{tabular}

* B = Birmingham Steel Corp.; C = Chaparral Steel Co.; and S = Structural Metals, Inc.

${ }^{\dagger}$ Average height of deformations $h_{r}$ is determined from measurements made on not less than two typical deformations on each side of bar. Determinations are based on five measurements per deformation: one at center of overall length, two at ends of overall length, and two located halfway between center and ends. The measurements at ends of overall length are averaged to obtain a single value and that value is combined with other three measurements to obtain average rib height $h_{r}$

${ }^{\ddagger}$ Thickness of the longitudinal rib.

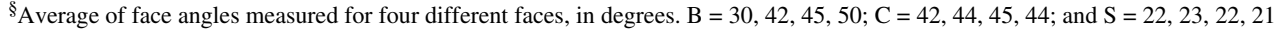

"Ratio of projected rib area normal to bar axis to product of nominal bar perimeter and average center-to-center rib spacing (ACI 408.3 ).

Note: $25.4 \mathrm{~mm}=1 \mathrm{in}$. 
Table 2-Concrete mixture proportions and properties (cubic meter batch)

\begin{tabular}{|c|c|c|c|c|c|c|c|c|c|}
\hline Group & $w / c$ & Cement, kg & Water, kg & Fine aggregate, ${ }^{*} \mathrm{~kg}$ & Coarse aggregate, ${ }^{\dagger} \mathrm{kg}$ & Slump, mm & $\begin{array}{c}\text { Concrete } \\
\text { temperature, } \mathrm{C}\end{array}$ & Age at test, days & $\begin{array}{l}\text { Average compressive } \\
\text { strength, } \mathrm{MPa}\end{array}$ \\
\hline \multirow{2}{*}{1} & \multirow{2}{*}{0.49} & \multirow{2}{*}{299} & \multirow{2}{*}{146} & \multirow{2}{*}{914} & \multirow{2}{*}{971} & \multirow{2}{*}{40} & \multirow{2}{*}{22} & 13 & 34.4 \\
\hline & & & & & & & & 14 & 34.4 \\
\hline \multirow{2}{*}{2} & \multirow{2}{*}{0.48} & \multirow{2}{*}{300} & \multirow{2}{*}{144} & \multirow{2}{*}{917} & \multirow{2}{*}{974} & \multirow{2}{*}{95} & \multirow{2}{*}{23} & 21 & 32.5 \\
\hline & & & & & & & & 22 & 32.8 \\
\hline \multirow{2}{*}{3} & \multirow{2}{*}{0.45} & \multirow{2}{*}{303} & \multirow{2}{*}{135} & \multirow{2}{*}{927} & \multirow{2}{*}{927} & \multirow{2}{*}{65} & \multirow{2}{*}{26} & 25 & 32.6 \\
\hline & & & & & & & & 26 & 32.8 \\
\hline
\end{tabular}

Kansas River sand: bulk specific gravity $(\mathrm{ssd})=2.62$; absorption $=0.5 \%$; fineness modulus $=3.0$.

${ }^{\dagger}$ Crushed limestone: bulk specific gravity $(\mathrm{ssd})=2.58$; absorption $=2.7 \%$; maximum size $=19 \mathrm{~mm}(3 / 4 \mathrm{in}$. $)$; unit weight $=1450 \mathrm{~kg} / \mathrm{m}^{3}\left(90.5 \mathrm{lb} / \mathrm{ft}^{3}\right)$.

Note: $1 \mathrm{~kg} / \mathrm{m}^{3}=1.69 \mathrm{lb} / \mathrm{yd}^{3} ; 1 \mathrm{MPa}=145 \mathrm{psi}$.

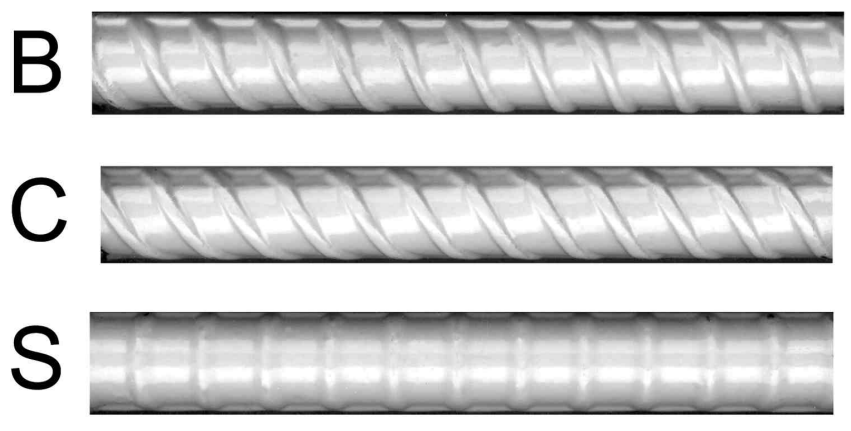

Fig. 2-Reinforcing bar deformation patterns.

were measured using a pull-off type gage (ASTM A 775). Coating measurements were taken at five points along the bonded length on each side of the test bars. The average of these measurements was used to analyze the effects of coating thickness on bond strength.

Concrete-Air-entrained concrete was supplied by a local ready-mix plant. The concrete contained Type I portland cement, $19 \mathrm{~mm}(3 / 4 \mathrm{in}$.) nominal maximum size crushed limestone, and Kansas River sand. The concrete was cast with water-cement ratios $(w / c)$ between 0.44 and 0.49 , providing a nominal strength of about $34 \mathrm{MPa}$ (5000 psi). Mixture proportions and concrete properties are listed in Table 2.

\section{Placement procedure}

Concrete was placed in two lifts of nearly equal volume. Each specimen received its first lift before any specimen received a second lift. After each lift was placed, the specimens were vibrated at four points, starting at the end closest to the bonded length. Standard test cylinders were cast according to ASTM C 192 and cured side by side with the test specimens. Forms were stripped after the concrete had reached a minimum compressive strength of $19 \mathrm{MPa}(2700 \mathrm{psi})$.

The test specimens were cast in three batches, each covering the full range of deformation patterns and coating thicknesses. Each batch was placed with the specimens arranged in a different order so as not to create systematic differences in bond strength due to differences in concrete properties from different portions of the discharge of the ready-mix truck. Forms were grouped by deformation pattern because differences in bond strength between deformation patterns are not a consideration in this study. To limit bias due to differences in concrete properties, forms with coated and uncoated bars were alternated. Coated bars were placed in a different order (based on coating thickness) in each batch, so that no three bars had either an ascending or descending coating thickness order.

\section{Test procedure}

Specimens were tested in accordance with ASTM A 944. Each group of specimens was tested over a $48 \mathrm{~h}$ period at concrete strengths between 32 and $35 \mathrm{MPa}$ (4700 and $5000 \mathrm{psi}$ ). Load was applied at a rate of about $15 \mathrm{kN}$ (3.5 kips) per min.

Displacement of the test bar at both the loaded and unloaded ends was measured using spring-loaded linear variable differential transformers (LVDTs). Loaded end slip LVDTs were mounted on a yoke attached to the test bar $127 \mathrm{~mm}$ (5 in.) from the front face of the specimen, and the reported values of loaded end slip include elastic lengthening of the test bar between the yoke and the face of the test specimen.

\section{RESULTS AND DISCUSSION \\ Load-slip curves and cracking patterns}

Load-slip curves for the test specimens for one group of B pattern bars are shown in Fig. 3 and 4. The load-loaded end slip curves (Fig. 3) exhibit significant scatter, with the coated and uncoated bars exhibiting similar stiffness. In contrast, the load-unloaded end slip curves (Fig. 4) for the uncoated bars are nearly always stiffer than the matching curves for the coated bars because unloaded slip is sensitive to the bond properties along the full embedded length of the bar.

Cracking patterns were similar for all specimens. As observed in earlier studies (Choi et al. 1990, Darwin and Graham 1993), a small, thin longitudinal crack began at the front of the top of the specimen just before failure, and with failure, widened, lengthened, and ended in an inverted $\mathrm{T}$ at the middle of the top face. On the front face of the specimen, cracking occurred in an inverted $\mathrm{Y}$, splitting around the test bar. Specimens with epoxy-coated test bars failed with a bang, but specimens with uncoated test bars failed more quietly.

When concrete was chipped away after testing, the epoxycoated bars showed no sign of having bonded with the concrete, as is usual. Coated bars were clean, and the concrete that had been in contact with them was smooth. For the uncoated test bars, some concrete remained stuck to the bars, and concrete powder was visible on the front side of the ribs. The concrete that had been in contact with the uncoated test bars was rougher than the concrete that had been in contact with the epoxy-coated bars.

\section{Bond strength}

Bond strengths are given in Table 3, along with coating thicknesses, covers, and concrete strengths. Modified bond strengths are calculated to account for differences in concrete strength and deviations in cover from the nominal value of 
$38 \mathrm{~mm}$ (1.5 in.). To do this, test strengths are normalized to a concrete strength of $34 \mathrm{MPa}$ (5000 psi), using the assumption that bond strength is proportional to the $1 / 4$ power of the compressive strength (Darwin et al. 1995, 1996; Zuo and Darwin 2000), and to a cover of $38 \mathrm{~mm}$ (1.5 in.) using the assumption that bond strength is directly proportional to the cover to the center of the bar (Darwin et al. 1995, 1996; Zuo and Darwin 2000). Thus, bond strengths are multiplied by $\left.\left(34 / f_{c}^{\prime}\right)^{1 / 4} 47.6 /\left(9.5+c_{b}\right)\left(\left[5000 / f_{c}^{\prime}\right)\right]^{174} 1.875 /\left[0.375+c_{b}\right]\right)$, where $f_{c}^{\prime}$ and $c_{b}$ are the measured compressive strength and cover, respectively. To establish the effect of the epoxy coating, the modified bond strength of each epoxy-coated bar is then divided by the average strength of the uncoated bars from the same test group with the same deformation pattern to obtain the ratio of the bond strength of the epoxy-coated bar to the bond strength of the uncoated bars, or the $C / U$ ratio.

The effect of coating thickness on the $C / U$ ratio is analyzed using the technique of dummy variables (Draper and Smith 1981). Application of this technique is based on the assumption that the effect of epoxy coating on bond strength may be different for different deformation patterns but that the effect of coating thickness on bond strength is the same for all patterns.

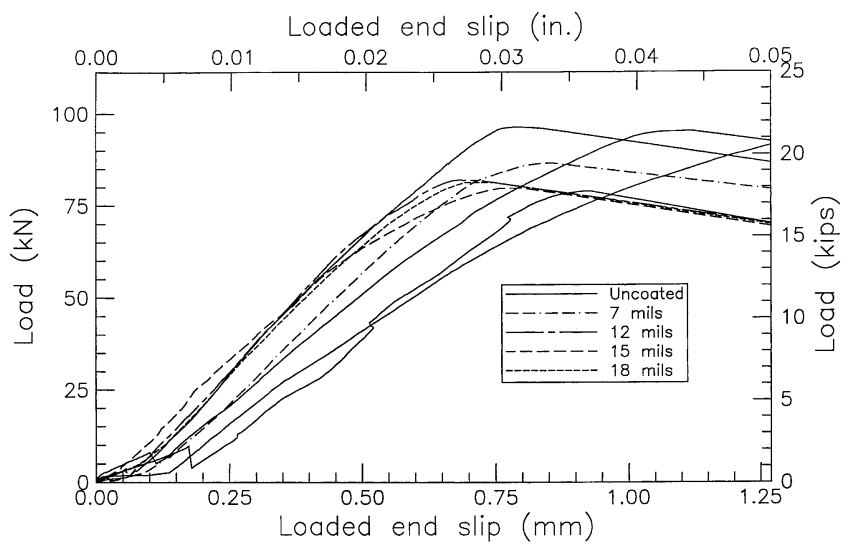

Fig. 3-Load versus loaded end slip for B-pattern bars (Test Group B).
As will be demonstrated in Fig. 5 to 7, the magnitude of the effect of the coating is actually quite similar for the three deformation patterns tested. The similarity in the effect of coating thickness also appears to be justified based on the relationship of the data points to the best-fit lines, as it was in the earlier work by Choi et al. $(1990,1991)$.

Best-fit lines for $C / U$ ratio versus coating thickness established using this technique are shown in Fig. 5. The general trend of the best-fit lines is a reduction in the $C / U$ ratio with an increase in coating thickness for the full range of coating thicknesses evaluated. The test results show significant scatter, as expected for bond tests.

Three of the data points for C-pattern bars may be considered to be unrepresentative. One specimen, with a coating thickness of $187 \mu \mathrm{m}(7.35$ mils) and a $C / U$ ratio of 0.856 , was cast in the first batch with the first concrete discharged from the ready-mix truck. Its strength is low for C-pattern bars with a nominal thickness of $175 \mu \mathrm{m}(7 \mathrm{mils})$. The strength of a second specimen, with a coating thickness of $353 \mu \mathrm{m}$ (13.9 mils), is significantly higher than any of the other specimens, while the bond strength of a third specimen, with a coating thickness of $394 \mu \mathrm{m}(15.5$ mils $)$ and a $C / U$ ratio of

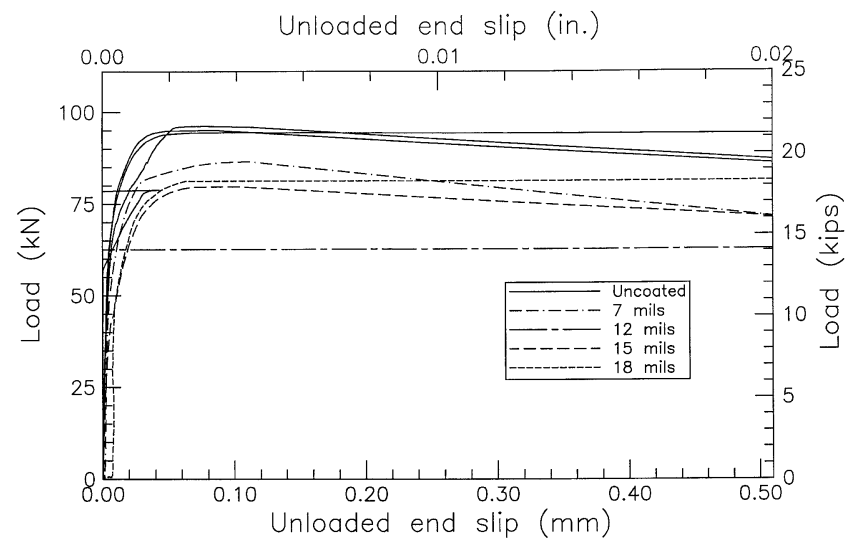

Fig. 4-Load versus unloaded end slip for B-pattern bars (Test Group B).

Table 3-Test results

\begin{tabular}{|c|c|c|c|c|c|c|c|}
\hline Test group & Specimen label & Coating thickness, $\mu \mathrm{m}$ & Cover, mm & Concrete strength, $\mathrm{MPa}$ & Bond force, $\mathrm{kN}$ & Modified bond force, ${ }^{*} \mathrm{kN}$ & $C / U$ ratio $^{\dagger}$ \\
\hline $\mathrm{A}$ & BA1 & 0 & 38.1 & 34.4 & 70.3 & 70.3 & - \\
\hline $\mathrm{A}$ & BA2 & 0 & 39.7 & 34.4 & 86.1 & 83.3 & - \\
\hline $\mathrm{A}$ & BA3 & 0 & 42.9 & 34.4 & 102.8 & 93.5 & - \\
\hline A & BA4 & 0 & 39.7 & 34.4 & 103.3 & 100.0 & - \\
\hline A & B7A & 199 & 38.1 & 34.4 & 80.3 & 80.3 & 0.925 \\
\hline $\mathrm{A}$ & B12A & 314 & 39.7 & 34.4 & 93.0 & 90.0 & 0.981 \\
\hline $\mathrm{A}$ & B15A & 380 & 38.1 & 34.4 & 82.3 & 82.3 & 0.948 \\
\hline A & B18A & 504 & 41.3 & 34.4 & 80.2 & 75.2 & 0.866 \\
\hline $\mathrm{A}$ & CA1 & 0 & 38.1 & 34.4 & 87.9 & 88.0 & - \\
\hline $\mathrm{A}$ & CA2 & 0 & 39.9 & 34.4 & 89.4 & 86.2 & - \\
\hline A & CA3 & 0 & 38.1 & 34.4 & 89.8 & 89.8 & - \\
\hline $\mathrm{A}$ & CA4 & 0 & 39.7 & 34.4 & 84.8 & 82.1 & - \\
\hline A & C7A & 187 & 39.7 & 34.4 & 76.6 & 74.2 & 0.856 \\
\hline A & $\mathrm{C} 12 \mathrm{~A}$ & 342 & 38.1 & 34.4 & 79.6 & 79.6 & 0.919 \\
\hline A & $\mathrm{C} 15 \mathrm{~A}$ & 414 & 36.5 & 34.4 & 77.7 & 80.4 & 0.929 \\
\hline $\mathrm{A}$ & $\mathrm{C} 18 \mathrm{~A}$ & 506 & 39.7 & 34.4 & 73.6 & 71.3 & 0.823 \\
\hline $\mathrm{A}$ & SA1 & 0 & 39.7 & 34.4 & 81.0 & 78.4 & - \\
\hline A & SA2 & 0 & 38.1 & 34.4 & 73.6 & 73.7 & - \\
\hline
\end{tabular}


Table 3-Test results (cont.)

\begin{tabular}{|c|c|c|c|c|c|c|c|}
\hline Test group & Specimen label & Coating thickness, $\mu \mathrm{m}$ & Cover, $\mathrm{mm}$ & Concrete strength, $\mathrm{MPa}$ & Bond force, $\mathrm{kN}$ & Modified bond force, ${ }^{*} \mathrm{kN}$ & $C / U$ ratio $^{\dagger}$ \\
\hline A & SA3 & 0 & 38.1 & 34.4 & 84.7 & 84.7 & - \\
\hline A & SA4 & 0 & 42.9 & 34.4 & 82.6 & 75.2 & - \\
\hline $\mathrm{A}$ & S7A & 204 & 42.9 & 34.4 & 73.7 & 67.0 & 0.859 \\
\hline $\mathrm{A}$ & S12A & 375 & 39.7 & 34.4 & 83.8 & 81.2 & 1.021 \\
\hline A & S15A & 420 & 39.7 & 34.4 & 75.8 & 73.3 & 0.940 \\
\hline A & S18A & 493 & 41.3 & 34.4 & 76.4 & 71.7 & 0.919 \\
\hline $\mathrm{B}$ & BB1 & 0 & 39.7 & 32.5 & 94.7 & 93.0 & - \\
\hline $\mathrm{B}$ & BB2 & 0 & 38.1 & 32.5 & 95.3 & 96.7 & - \\
\hline $\mathrm{B}$ & BB3 & 0 & 38.1 & 32.8 & 79.0 & 80.0 & - \\
\hline $\mathrm{B}$ & BB4 & 0 & 50.8 & 32.8 & 96.4 & 77.1 & - \\
\hline B & B7B & 175 & 38.1 & 32.5 & 86.2 & 87.9 & 1.014 \\
\hline $\mathrm{B}$ & B12B & 342 & 36.5 & 32.8 & 82.1 & 86.0 & 0.992 \\
\hline $\mathrm{B}$ & B15B & 392 & 38.1 & 32.8 & 79.9 & 80.9 & 0.933 \\
\hline $\mathrm{B}$ & B18B & 465 & 39.7 & 32.5 & 81.6 & 80.1 & 0.924 \\
\hline $\mathrm{B}$ & $\mathrm{CB} 2$ & 0 & 38.1 & 32.5 & 91.8 & 93.2 & - \\
\hline B & CB3 & 0 & 38.1 & 32.8 & 79.2 & 80.2 & - \\
\hline B & CB4 & 0 & 38.1 & 32.8 & 83.5 & 84.6 & - \\
\hline $\mathrm{B}$ & C7A-B & 176 & 39.9 & 32.5 & 87.8 & 85.8 & 0.998 \\
\hline B & C7B & 184 & 42.9 & 32.5 & 92.6 & 85.4 & 0.994 \\
\hline B & $\mathrm{C} 12 \mathrm{~B}$ & 353 & 31.8 & 32.8 & 83.2 & 97.3 & 1.131 \\
\hline B & C15B & 423 & 33.3 & 32.5 & 74.6 & 84.1 & 0.978 \\
\hline B & C18B & 488 & 39.7 & 32.8 & 74.0 & 72.5 & 0.843 \\
\hline $\mathrm{B}$ & SB1 & 0 & 36.7 & 32.5 & 90.6 & 94.5 & - \\
\hline B & SB2 & 0 & 39.7 & 32.5 & 87.7 & 86.2 & - \\
\hline B & SB3 & 0 & 42.9 & 32.5 & 89.5 & 82.6 & - \\
\hline $\mathrm{B}$ & SB4 & 0 & 44.4 & 32.5 & 90.3 & 80.9 & - \\
\hline B & S7B & 164 & 41.3 & 32.8 & 78.0 & 74.1 & 0.861 \\
\hline B & S12B & 371 & 42.9 & 32.5 & 80.7 & 74.5 & 0.866 \\
\hline B & S15B & 418 & 44.4 & 32.8 & 86.9 & 77.7 & 0.903 \\
\hline B & S18B & 461 & 41.3 & 32.8 & 77.6 & 73.7 & 0.857 \\
\hline $\mathrm{C}$ & $\mathrm{BC} 1$ & 0 & 39.7 & 32.8 & 79.5 & 77.9 & - \\
\hline $\mathrm{C}$ & $\mathrm{BC} 2$ & 0 & 42.9 & 32.8 & 105.9 & 97.5 & - \\
\hline $\mathrm{C}$ & $\mathrm{BC} 3$ & 0 & 34.9 & 32.8 & 101.3 & 109.9 & - \\
\hline $\mathrm{C}$ & BC4 & 0 & 36.5 & 32.8 & 83.3 & 87.3 & - \\
\hline $\mathrm{C}$ & B7C & 181 & 38.1 & 32.8 & 82.6 & 83.6 & 0.897 \\
\hline $\mathrm{C}$ & B12C & 333 & 39.7 & 32.8 & 95.6 & 93.6 & 1.005 \\
\hline $\mathrm{C}$ & B15C & 410 & 38.1 & 32.8 & 84.9 & 85.9 & 0.923 \\
\hline $\mathrm{C}$ & B18C & 437 & 41.3 & 32.8 & 82.6 & 78.4 & 0.841 \\
\hline $\mathrm{C}$ & $\mathrm{CC} 1$ & 0 & 42.9 & 32.6 & 99.9 & 92.2 & - \\
\hline $\mathrm{C}$ & $\mathrm{CC} 2$ & 0 & 39.7 & 32.6 & 94.8 & 93.1 & - \\
\hline $\mathrm{C}$ & $\mathrm{CC} 3$ & 0 & 41.3 & 32.8 & 88.1 & 83.6 & - \\
\hline $\mathrm{C}$ & $\mathrm{CC} 4$ & 0 & 42.9 & 32.6 & 90.2 & 83.2 & - \\
\hline $\mathrm{C}$ & C7C & 162 & 38.1 & 32.6 & 85.1 & 86.3 & 0.981 \\
\hline $\mathrm{C}$ & $\mathrm{C} 12 \mathrm{C}$ & 308 & 36.5 & 32.8 & 87.4 & 91.6 & 1.040 \\
\hline $\mathrm{C}$ & $\mathrm{C} 15 \mathrm{C}$ & 394 & 41.3 & 32.8 & 70.7 & 67.1 & 0.762 \\
\hline $\mathrm{C}$ & $\mathrm{C} 18 \mathrm{C}$ & 466 & 38.1 & 32.6 & 81.3 & 82.5 & 0.937 \\
\hline $\mathrm{C}$ & SC1 & 0 & 41.3 & 32.8 & 92.8 & 88.1 & - \\
\hline $\mathrm{C}$ & SC2 & 0 & 36.5 & 32.8 & 76.3 & 80.1 & - \\
\hline $\mathrm{C}$ & SC3 & 0 & 41.3 & 32.6 & 79.1 & 75.2 & - \\
\hline $\mathrm{C}$ & SC4 & 0 & 39.7 & 32.6 & 79.1 & 77.7 & - \\
\hline $\mathrm{C}$ & S7C & 187 & 39.7 & 32.6 & 76.2 & 74.8 & 0.932 \\
\hline $\mathrm{C}$ & S12C & 338 & 38.1 & 32.6 & 79.7 & 80.9 & 1.008 \\
\hline $\mathrm{C}$ & S15C & 412 & 39.7 & 32.6 & 88.7 & 87.1 & 1.085 \\
\hline $\mathrm{C}$ & S18C & 486 & 36.5 & 32.6 & 73.5 & 77.2 & 0.961 \\
\hline
\end{tabular}

*Modified bond force $=$ test force $(34 \mathrm{MPa} / \text { concrete strength })^{1 / 4} 47.6 \mathrm{~mm} /(9.5 \mathrm{~mm}+$ cover $)$.

${ }^{\dagger} \mathrm{C} / U$ ratio $=$ ratio of modified bond force of coated bar to average bond for uncoated bars with same deformation pattern in same test group.

Note: $25.4 \mu \mathrm{m}=1 \mathrm{mil} ; 25.4 \mathrm{~mm}=1$ in.; $1 \mathrm{MPa}=145 \mathrm{psi} ; 1 \mathrm{kN}=0.225$ kip. 


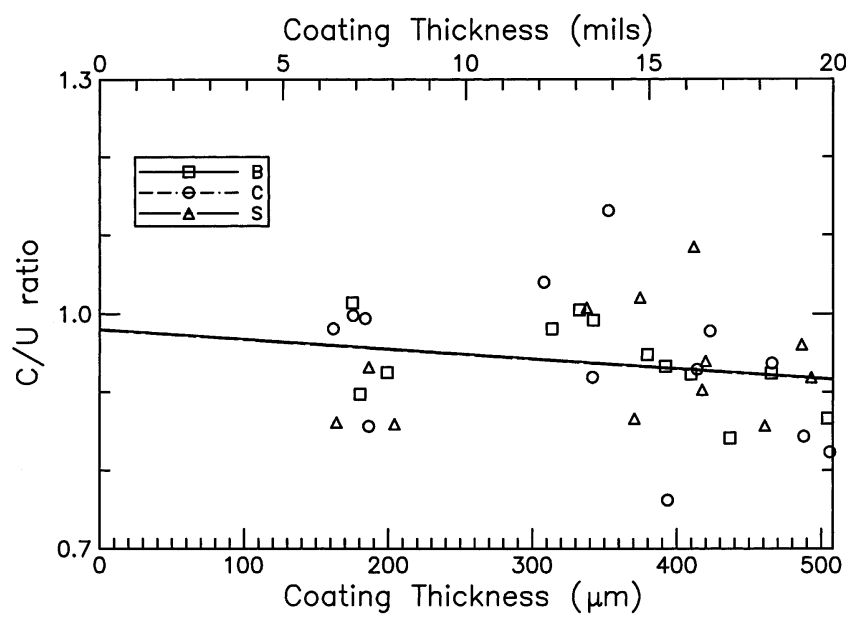

Fig. 5-C/U ratio versus coating thickness for coatings between 160 and $510 \mu \mathrm{m}$ (6.4 to 19.9 mils).

0.762 , is significantly weaker. These three specimens were removed from the database to limit their effect on the analysis. As shown in Fig. 6, however, removal of the three data points has little effect on the observed trend, an overall decrease in bond strength as the coating thickness increases from 160 to $510 \mu \mathrm{m}$ (6.4 to $19.9 \mathrm{mils})$; the slope of the best-fit lines is, in fact, somewhat more negative after removing the three data points, emphasizing the negative impact of large increases in coating thickness.

The next step in the analysis involves the removal of the data points corresponding to the bars with the thickest coatings to determine if there is a range of coating thickness over which the $C / U$ ratio is not affected.

As shown in Fig. 7, once the data for bars with coatings in excess of $430 \mu \mathrm{m}$ (17 mils) are removed, the overall trend of the data actually changes to a slight increase in $C / U$ ratio as coating thicknesses increase from $160 \mu \mathrm{m}$ (6.4 mils) to a maximum value of $423 \mu \mathrm{m}$ (16.65 mils). (As an aside, the slope of the line is even higher if the three excluded data points are incorporated in the analysis. The small positive slope is the result of scatter in the data and should not be construed to mean that thicker coatings give higher bond strengths.) Thus, $420 \mu \mathrm{m}$ (16.5 mils) appears to be a safe upper bound on coating thickness.

Prior research (Choi et al. 1990, 1991) demonstrates that the bond strength of epoxy-coated No. 25 (No. 8) bars is not sensitive to coating thickness for coatings up to approximately $410 \mu \mathrm{m}$ (16 mils) thick, the upper limit on the data. Most of the data on the No. 25 (No. 8) bars, however, are for bars with coatings with thicknesses of $355 \mu \mathrm{m}$ (14 mils) or less. As observed earlier, the work by Choi et al. (1990, 1991) and Hester et al. (1991) also demonstrates that bond strength drops significantly with increasing coating thickness for No. 16 (No. 5) and smaller bars.

When combined with the earlier work, the current study indicates that it is realistic to allow an increase in the maximum coating thickness from $300 \mu \mathrm{m}$ (12 mils) to $420 \mu \mathrm{m}$ (16.5 mils) for No. 19 (No. 6) and larger bars meeting the requirements of ASTM A 775. The maximum coating thickness for smaller bars should remain $300 \mu \mathrm{m}$ (12 mils).

\section{CONCLUSIONS}

The following conclusions are based on the results and analysis presented in this paper.

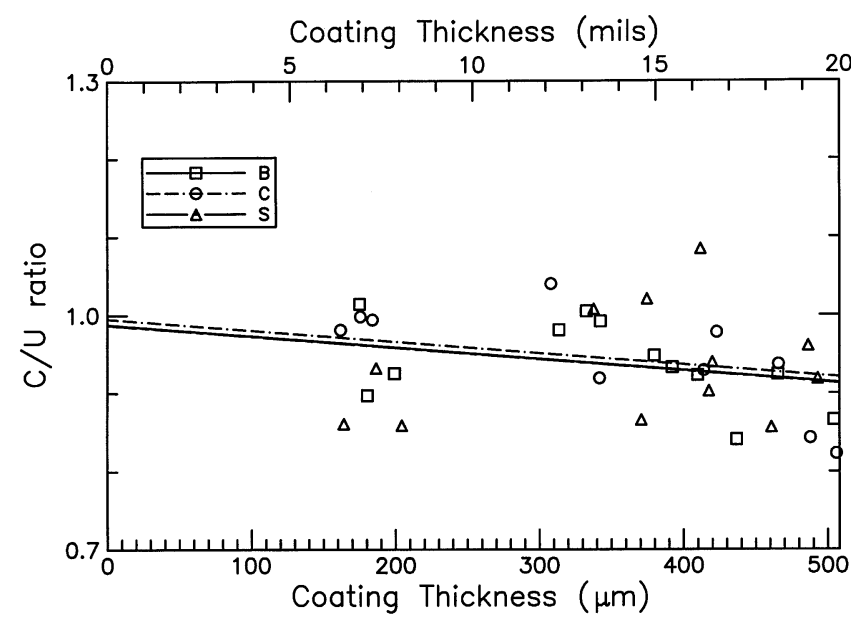

Fig. 6-C/U ratio versus coating thickness for coatings between 160 and $510 \mu \mathrm{m}$ (6.4 to 19.9 mils), with unrepresentative test results removed.

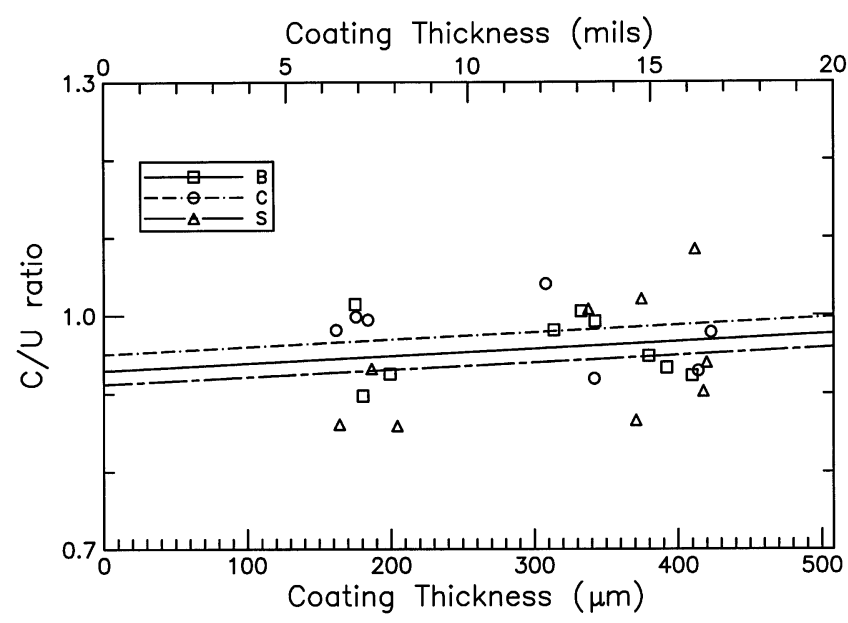

Fig. 7- $\mathrm{C} / \mathrm{U}$ ratio versus coating thickness for coatings between 160 and $420 \mu \mathrm{m}$ (6.4 to 16.5 mils).

1. ASTM A 775 epoxy coatings with thicknesses in the range of 160 to $510 \mu \mathrm{m}$ (6.4 to 19.9 mils) reduce the bond strength of deformed No. 19 (No. 6) reinforcing bars to concrete.

2. For ASTM A 775 epoxy coatings with a thickness between 160 and $420 \mu \mathrm{m}$ (6.4 and 16.5 mils), differences in coating thickness have little effect on the amount of bond strength reduction for No. 19 (No. 6) and, by extension, larger bars. For No. 19 (No. 6) bars, coatings thicker than $420 \mu \mathrm{m}$ (16.5 mils) cause an additional drop in bond strength relative to the bond strength obtained with thinner coatings.

3. The maximum allowable coating thickness should be increased from 300 to $420 \mu \mathrm{m}$ ( 12 to 16.5 mils) for No. 19 (No. 6) and larger bars meeting the requirements of ASTM A 775 .

\section{ACKNOWLEDGMENTS}

Support for this research was provided by the National Science Foundation through NSF Grant No. CMS-9402563, ABC Coating, Inc., Akzo Nobel, Birmingham Steel Corporation, Chaparral Steel Company, Midwest Pipe Coating, Inc., and Dayton Richmond.

\section{REFERENCES}

AASHTO Highway Sub-Committee on Bridges and Structures, 1996 , Standard Specifications for Highway Bridges, 16th Edition, American 
Association of State Highway and Transportation Officials, Washington, D.C., 677 pp.

ACI Committee 318, 2002, "Building Code Requirements for Structural Concrete (ACI 318-02) and Commentary (318R-02)," American Concrete Institute, Farmington Hills, Mich., 443 pp.

ACI Committee 408, 2001, "Splice and Development Length of High Relative Rib Area Reinforcing Bars in Tension (ACI 408.3-01) and Commentary (408.3R-01)," American Concrete Institute, Farmington Hills, Mich., 6 pp.

ASTM, 1999, "Standard Test Method for Comparing Bond Strength of Steel Reinforcing Bars to Concrete Using Beam-End Specimens (ASTM A 944-99)," 2001 Annual Book of ASTM Standards, V. 01.04, West Conshohocken, Pa., pp. 501-504.

ASTM, 2000, "Practice for Making and Curing Concrete Test Specimens in the Laboratory (ASTM C 192/C 192M-00)," 2001 Annual Book of ASTM Standards, V. 04.02, West Conshohocken, Pa., pp. 120-127.

ASTM, 2000, "Specification for Epoxy-Coated Prefabricated Reinforcing Bars (ASTM A 934/A 934M-00)," 2001 Annual Book of ASTM Standards, V. 01.04, West Conshohocken, Pa., pp. 485-500.

ASTM, 2000, "Standard Specification for Deformed and Plain BilletSteel Bars for Concrete Reinforcement (ASTM A 615/615M-00a)," 2001 Annual Book of ASTM Standards, V. 01.04, West Conshohocken, Pa., pp. 296-300.

ASTM, 2000, "Standard Specification for Epoxy-Coated Reinforcing Steel Bars (ASTM A 775/A775M-00)," 2001 Annual Book of ASTM Standards, V. 01.04, West Conshohocken, Pa., pp. 385-392.

Choi, O. C.; Hadje-Ghaffari, H.; Darwin, D.; and McCabe, S. L., 1990, "Bond of Epoxy-Coated Reinforcement to Concrete: Bar Parameters," SL Report 90-1, University of Kansas Center for Research, Lawrence, Kans., Jan., 43 pp.

Choi, O. C.; Hadje-Ghaffari, H.; Darwin, D.; and McCabe, S. L., 1991,
"Bond of Epoxy-Coated Reinforcement: Bar Parameters," ACI Materials Journal, V. 88, No. 2, Mar.-Apr., pp. 207-217.

Darwin, D., and Graham, E. K., 1993, "Effect of Deformation Height and Spacing on Bond Strength of Reinforcing Bars," SL Report 93-1, University of Kansas Center for Research, Lawrence, Kans., Jan., 68 pp.

Darwin, D.; Zuo, J.; Tholen, M. L.; and Idun, E. K., 1995, "Development Length Criteria for Conventional and High Relative Rib Area Reinforcing Bars," SL Report 95-4, University of Kansas Center for Research, Lawrence, Kans., May, 70 pp.

Darwin, D.; Zuo, J.; Tholen, M. L.; and Idun, E. K., 1996, "Development Length Criteria for Conventional and High Relative Rib Area Reinforcing Bars," ACI Structural Journal, V. 93, No. 3, May-June, pp. 347-359.

Draper, N. R., and Smith, H., 1981, Applied Regression Analysis, 2nd Edition, John Wiley \& Sons, Inc., pp. 241-249.

Hasan, H. O.; Cleary, D. B.; and Ramirez, J. A., 1996, "Performance of Concrete Bridge Decks and Slabs Reinforced with Epoxy-Coated Steel under Repeated Loading," ACI Structural Journal, V. 93, No. 4, July-Aug., pp. $397-403$

Hester, C. J.; Salamizavaregh, S.; Darwin, D.; and McCabe, S. L., 1991, "Bond of Epoxy-Coated Reinforcement to Concrete: Splices," SL Report 91-1, University of Kansas Center for Research, Lawrence, Kans., May, 66 pp.

Mathey, R. G., and Clifton, J. R., 1976, "Bond of Coated Reinforcing Bars in Concrete," Journal of the Structural Division, ASCE, V. 102, No. ST1, Jan., pp. 215-229.

Miller, G. G.; Kepler, J. L.; and Darwin, D., 1998, "Effect of Epoxy Coating on Bond Strength of No. 19 [No. 6] Reinforcing Bars," SL Report 98-1, University of Kansas Center for Research, Lawrence, Kansas, Jan., $26 \mathrm{pp}$.

Zuo, J., and Darwin, D., 2000, "Splice Strength of Conventional and High Relative Rib Area Bars in Normal and High Strength Concrete," ACI Structural Journal, V. 97, No. 4, July-Aug., pp. 630-641. 